\title{
Corroded steel support friction joint load capacity studies as found in Piast-Ziemowit coal mine
}

\begin{abstract}
This article presents the load capacity study results of the corroded friction joints obtained during heading relining conduction. The main goal of the study was to determine the operational characteristics of heavily corroded friction joints as well as their load capacity. An additional goal of the study was to indicate which parameter is crucial from the point of view of corroded support technical condition evaluation - friction joint load capacity or arch strength. Mine conditions in which the LP support operated were also briefly characterized in the article. The study presented in the article is of a pilot character; while the obtained results reveal a very significant influence of corrosion on the support operational safety, the studies of corroded joints will be continued in the future using a larger number of samples and various types of shackles.
\end{abstract}

Key words: corrosion, heading support, friction joints, load capacity study

\section{INTRODUCTION}

A steel frame support is the basic gallery working support utilized in Polish hard coal mines. The reasons for this are the many advantages of this type of support, including its easy adjustment to geological and mining conditions, fast manufacturing, relatively low cost, and wide array of available support size variants. Despite this, the steel frame support has one significant flaw; its load capacity changes over time together with the progressing corrosion of its frame. Thus, its durability is limited and dependent (among other things) on the aggressiveness of the environment in which it is utilized. Based on underground observations, it can be concluded that steel frame supports retain their functional quality over a period of several to dozens of years. It is obvious that specific steel support components are susceptible to aggressive environmental influence to a different extent.
Frame durability is considerably higher than that of thin-walled elements, such as wire mesh lining or frame sprags. While it is possible to supplement, replace, or apply repairs to most accessories in the event of significant corrosion, it is necessary to reinforce (underpin) or replace them in the case of frames, which results in costly heading reconstruction [1]. To avoid emergencies when support load capacity falls to the level of the load it is subjected to (and results in heading stability loss risks as well as caving and rock slide risks), mining staff should periodically conduct support technical condition controls. A number of corrosion studies have been conducted thus far (including concerning mining supports) [2-6], and many methodologies have been developed, making it possible to assess the load capacity of a corroded frame based on real V-section wall thickness measurements [7-11]. Friction joint load capacity is another very significant issue [12-15] 
that influences the frame spacing determined during support selection [16-18], though it is omitted in the referenced corroded support assessment methodologies. This is due to the fact that, in underground conditions, it is difficult to determine or at least estimate the load capacity of friction joints in which support arch consolidation occurred as a result of crevice corrosion. This particularly concerns corroded frames, when it is difficult to determine the load capacity of a friction joint in an indirect way. To assess this load capacity, a series of bench studies were conducted on the frame friction joints obtained during heading relining conduction. An additional goal of the studies was to determine which parameter is crucial from the point of view of corroded support technical condition evaluation - friction joint load capacity or arch strength.

\section{MINE ENVIRONMENT CHARACTERISTICS IN OPERATION AREA OF STUDIED FRICTION JOINTS}

The mine environment changes along with characteristic factors such as hydrologic conditions, burial depth, humidity, surrounding rock virgin temperature, temperature of the machines and devices operating in a given heading, airflow, etc. Based on studies and observations, it was determined that mine water aggressiveness has the greatest influence on the corrosion process speed in the Piast-Ziemowit Ruch Ziemowit coal mine.
Four basic characteristics of mine water determine its aggressiveness:

- hydrogen ion concentration $(\mathrm{pH})$,

- total hardness,

- amount of chlorides,

- amount of sulfides.

Friction joint samples for laboratory testing were obtained from East Drift 930, Level III (650 m) during the relining conducted there. Basic data concerning the support has been collected in Table 1.

The support was set in 1998; therefore, it has been operational for 20 years. Breakaways of corrosion products and heavily corroded shackles were visible on the support arches. The environment in the sampling area was very aggressive. Relative air humidity in the heading was at a level of $88 \%$. Additionally, the analyzed water was characterized by very high mineralization; it contained $149,500 \mathrm{mg} / \mathrm{dm}^{3}$ of solutes and had high hardness $-1019^{\circ} \mathrm{n}$. The average chloride ion concentration of $84,373 \mathrm{mg} / \mathrm{dm}^{3}$ and sulfide of $3323 \mathrm{mg} / \mathrm{dm}^{3}$ at a significant layer of humidity on the support surface resulted in the acceleration of the corrosion processes. Furthermore, $3466 \mathrm{mg} / \mathrm{dm}^{3}$ of magnesium cations and $4280 \mathrm{mg} / \mathrm{dm}^{3}$ of calcium cations had an influence on the considerable water hardness.

Taking into account the time when the support was in operation and the very high mineralization of the water condensing on the support surface (high even for mine conditions) resulting in the acceleration of the corrosion processes, the support together with the friction joints in East Drift 930 can be considered heavily corroded.

Table 1

Steel support characteristics [19]

\begin{tabular}{|c|c|c|c|c|c|}
\hline $\begin{array}{c}\text { Frame } \\
\text { size }\end{array}$ & Section & $\begin{array}{c}\text { Grade } \\
\text { of steel }\end{array}$ & $\begin{array}{c}\text { Number } \\
\text { of shackles } \\
\text { in joint }\end{array}$ & $\begin{array}{c}\text { Shackle } \\
\text { type }\end{array}$ & $\begin{array}{c}\text { Year } \\
\text { of } \\
\text { setting }\end{array}$ \\
\hline LP9 & V29 & $25 \mathrm{G} 2$ & 2 & K29 & 1998 \\
\hline
\end{tabular}

Table 2

Physico-chemical properties of water in studied support operation area [19]

\begin{tabular}{|c|c|c|c|c|c|c|c|}
\hline \multirow{2}{*}{$\begin{array}{c}\text { Solutes } \\
{\left[\mathbf{m g} / \mathbf{d m}^{3}\right]}\end{array}$} & \multirow{2}{*}{$\mathbf{p H}$} & \multirow{2}{*}{$\begin{array}{c}\text { Total } \\
\text { hardness } \\
{\left[{ }^{\circ} \mathbf{n}\right]}\end{array}$} & \multicolumn{2}{|c|}{$\begin{array}{c}\text { Cations } \\
{\left[\mathbf{m g} / \mathbf{d m}^{3}\right]}\end{array}$} & \multicolumn{3}{|c|}{$\begin{array}{c}\text { Anions } \\
{\left[\mathbf{m g} / \mathbf{d m}^{3}\right]}\end{array}$} \\
\cline { 4 - 8 } & & & $\mathrm{Ca}^{+2}$ & $\mathrm{Mg}^{+2}$ & $\mathrm{Cl}^{-}$ & $\mathrm{SO}_{4}^{-2}$ & $\mathrm{HCO}_{3}^{-}$ \\
\hline 149,500 & 6.5 & 1386 & 4280 & 3466 & 84,373 & 3323 & 122 \\
\hline
\end{tabular}




\section{COURSE AND RESULTS OF STUDIES}

Bench tests were conducted on two LP support friction joints constructed from V29 sections, obtained during the relining of East Drift 930 at Level III in the Piast-Ziemowit Ruch Ziemowit coal mine.

Arcuate joint tests without passive pressure (passive force exerting influence on the joint) were conducted according to the load diagram presented in Figure 1 (based on standard PN-G-15026:2017-04) [20].

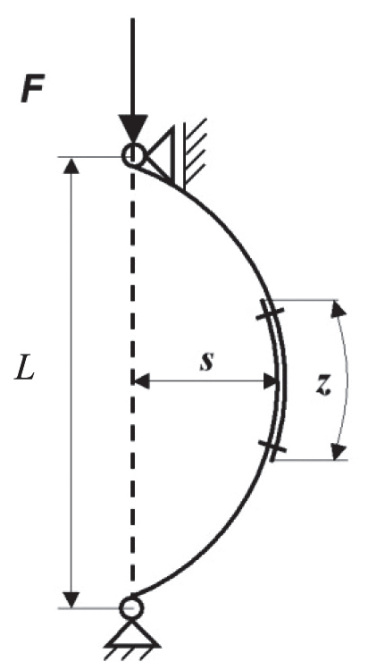

Fig. 1. Load diagram of arcuate joint subjected to force $F$ acting in fixed support pivot axis, where $L$ is the joint chord length, $s$-joint arrow length, and $z$ - overlap length

Negative bending moment value $M_{g}$ (decreasing the joint arch radius of curvature) in the joint crosssection (in the location of its arrow $s$ ) was calculated from the following formula:

$$
M_{g}=-F \cdot s[\mathrm{kN} \cdot \mathrm{m}]
$$

where:

$F$ - force loading the joint during its yield $[\mathrm{kN}]$,

$s$ - joint arrow length [m], calculated as the distance between the neutral axis of two V29 sections in the joint and the force $F$ axis.

The test stand was equipped with a hydraulic actuator with a strain gauge force sensor (operating in a full-bridge configuration) with a measuring range of up to $1000 \mathrm{kN}$ (Class 0.5), mounted on the piston rod and a potentiometric displacement transducer with a measuring range up to $1500 \mathrm{~mm}$ (Class 0.35 ) for joint chord length alteration $\Delta L$ measurement during its loading.
During testing, force $F$ loading the joint and joint chord length $L$ were measured with a sampling rate of $f_{p}=10 \mathrm{~Hz}$, which is sufficient to determine the operational characteristics of LP support frame friction joints (as demonstrated by the many years of friction joint studies within an accredited laboratory). The sensors were connected to a DMCPLUS-type measuring amplifier with an accuracy class of 0.03 . Measurement data was registered on a computer using the CATMAN program.

Before conducting the tests, the joints had an overlap of approx. $560 \mathrm{~mm}$, while the joint arrows $s$ were approx. $108 \mathrm{~mm}$ long (measured from the force $F$ axis to the joint neutral axis) [12-13].

The joint ends in contact with the tensile testing machine parallel loading plates were cut in such a way so they would adhere to the machine plates. Due to the fact that section perforations were found in the joint (Fig. 2), its ends were additionally reinforced with a V29 section segment and a single shackle. This was done to prevent the occurrence of V29 section deformations in the joint (which would block its yield) and, thus, disrupt the joint course of operation. A view of the joints prepared for testing is presented in Figures 3 and 4.

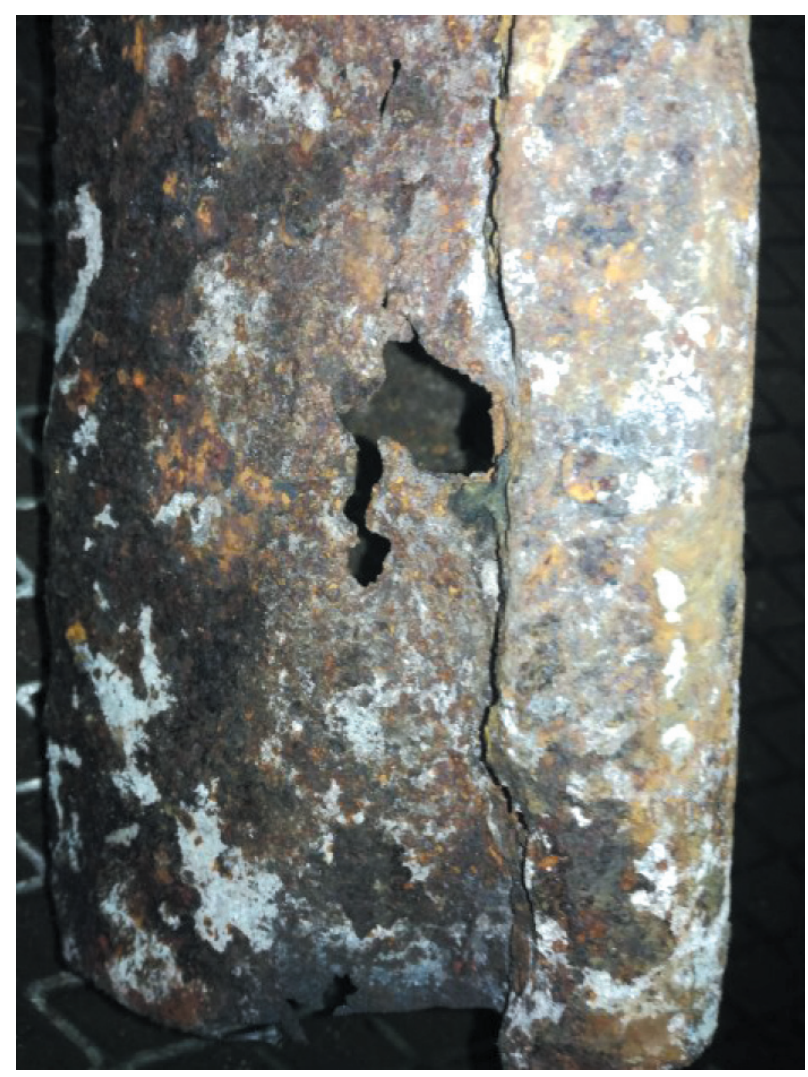

Fig. 2. Section perforation in flange area 

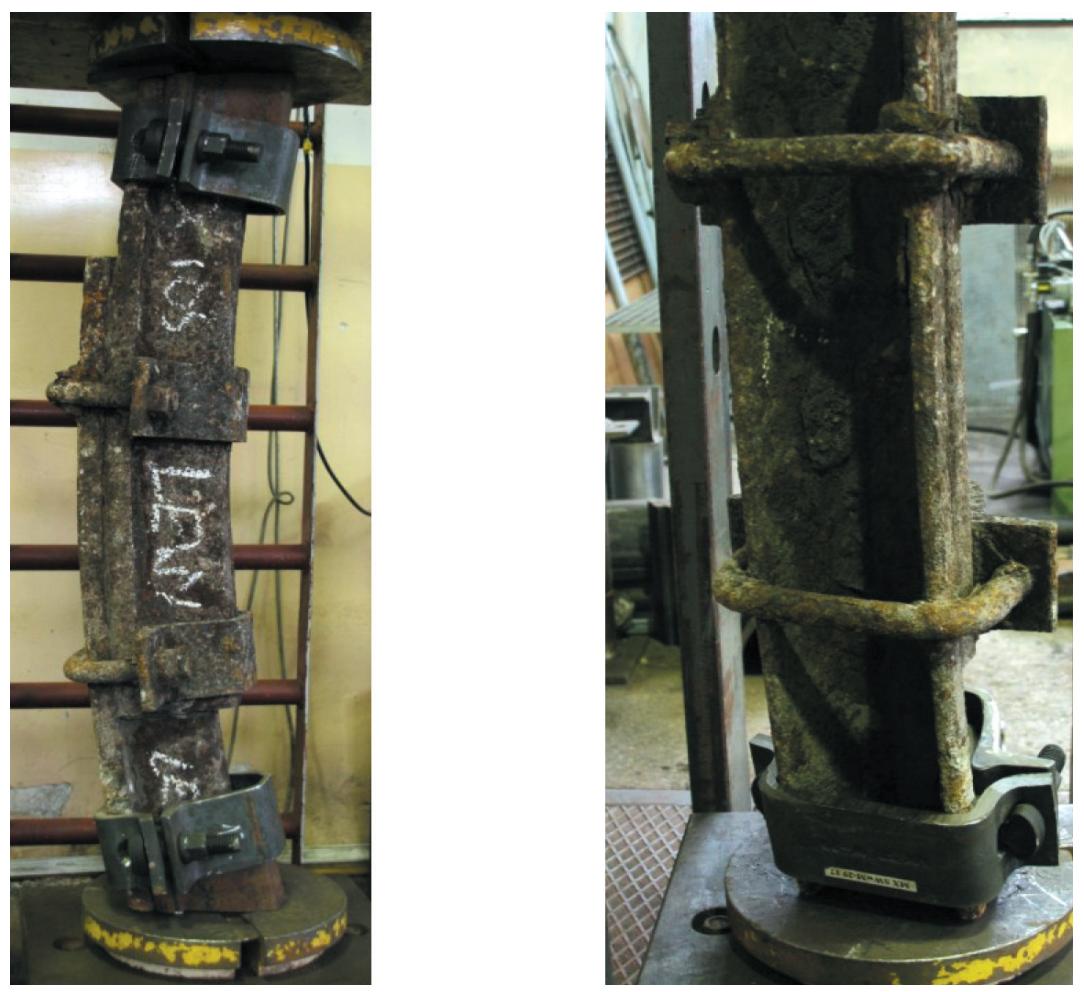

Fig. 3. Friction joint 1 prepared for testing and shackle technical condition
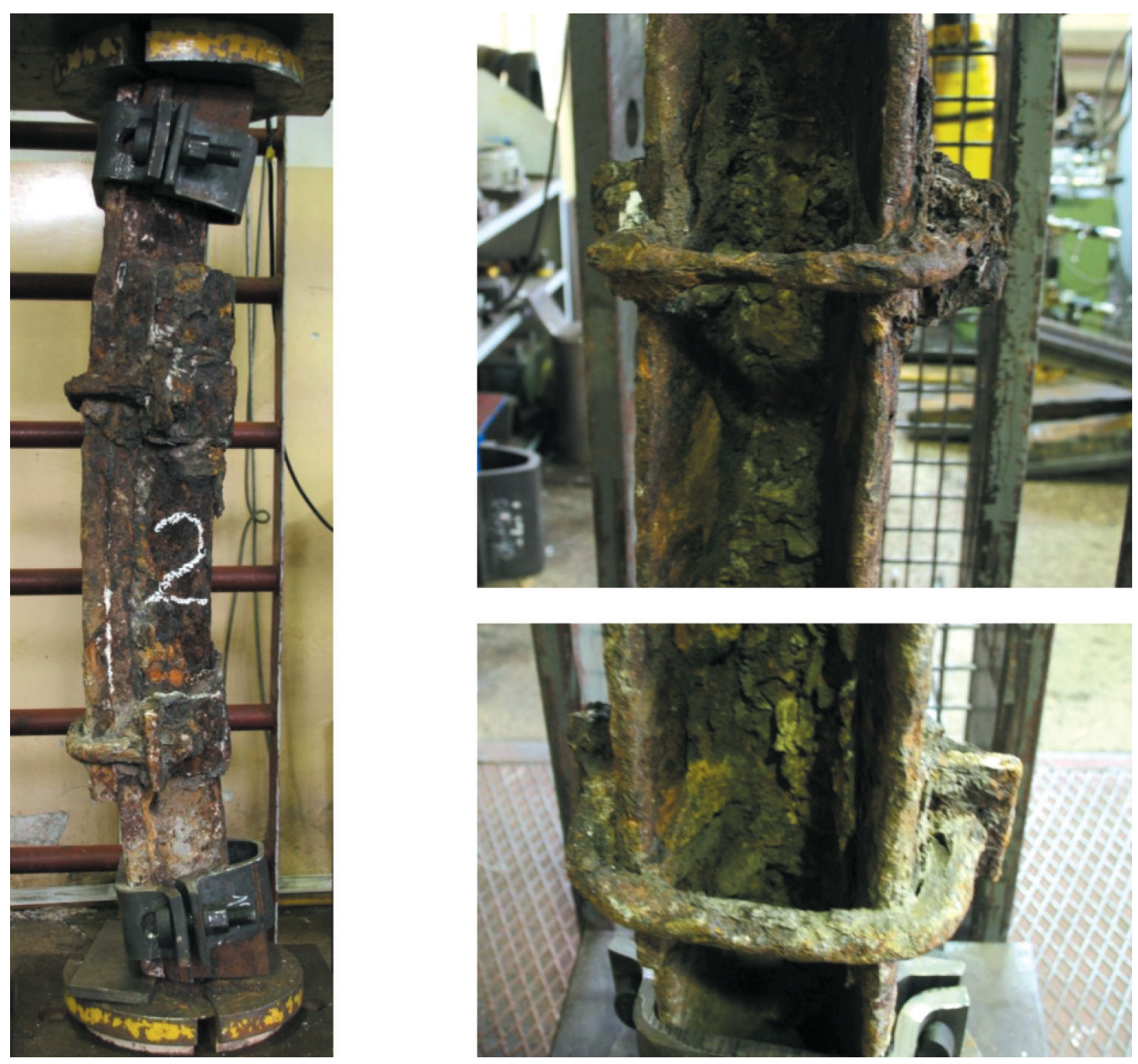

Fig. 4. Friction joint 2 prepared for testing and shackle technical condition 
Test results in the form of $F=f(\Delta L)$ courses are presented in Figures 5 and 6.

Geometric measurements of the K29 bow shackles in friction joint 1 showed that the M27 bow bolts exhibited slight corrosion resulting in bow diameter reduction within a range of $25-26 \mathrm{~mm}$ (both in the lower and upper shackles). The joint overlap of $z=560 \mathrm{~mm}$ did not change (neither before nor after testing).
During Test 1, the joint loaded with a force of $F=700 \mathrm{kN}$ at a bending moment of $M_{\mathrm{g}}=75.6 \mathrm{kNm}$ did not yield, and no plastic deformation was found in it after the test either. Arcuate joints constructed from V29 sections connected with two K29 shackles typically tend to yield at a loading force of approx. $220 \mathrm{kN}$. The blocking of the joint was most likely the result of crevice corrosion between the arches, which resulted in the locking of the sections and shackles in the joint.

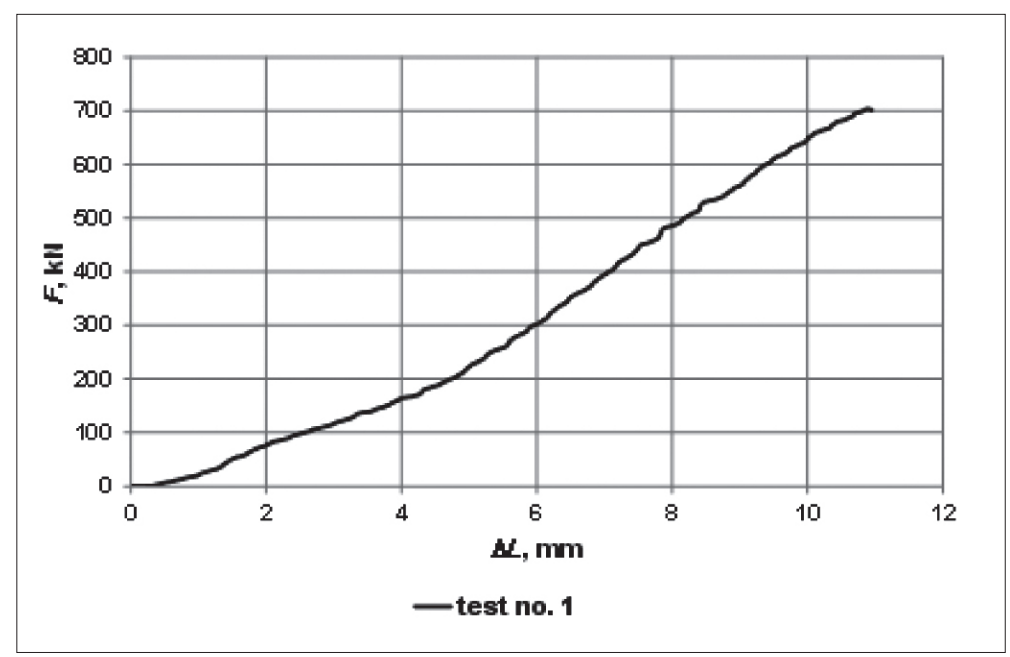

Fig. 5. Friction joint 1 characteristics

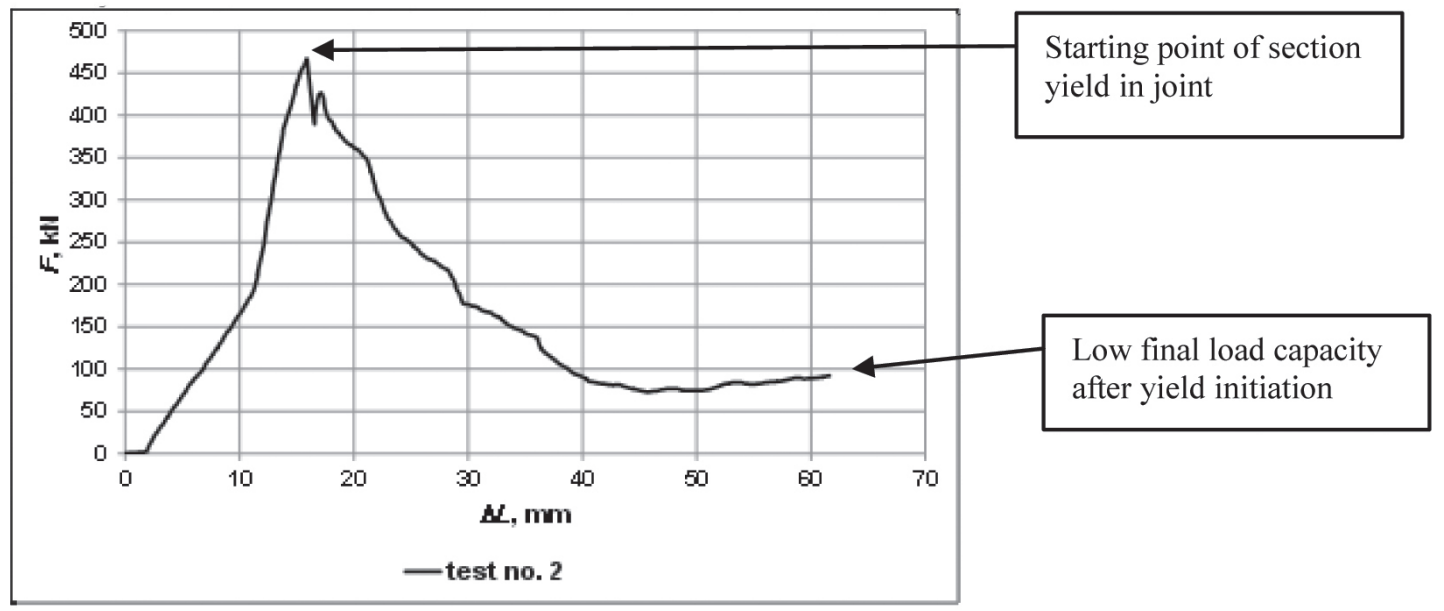

Fig. 6. Friction joint 2 characteristics

Geometric measurements of the K29 bow shackles in friction joint 2 showed that the M27 bow bolts exhibited significant corrosion resulting in bow diameter reduction within the ranges of $7-20 \mathrm{~mm}$ in the upper shackle and $18-23 \mathrm{~mm}$ in the lower shackle.

A different manner of operation was observed during Test 2. The joint loaded with a force of $F=467 \mathrm{kN}$ and a bending moment of $M_{\mathrm{g}}=50.4 \mathrm{kNm}$ did yield
(Fig. 8). The yield was a continuous yield, and the joint load capacity end value stabilized at a level of approx. $90 \mathrm{kN}$. No section plastic deformations in the joint were observed after the test either. The most likely cause of the joint yield and systematic decrease of its load capacity was the bad technical condition of the upper and lower shackle bow bolts as compared to the bow shackles utilized in Test 1 (Fig. 7). 
a)

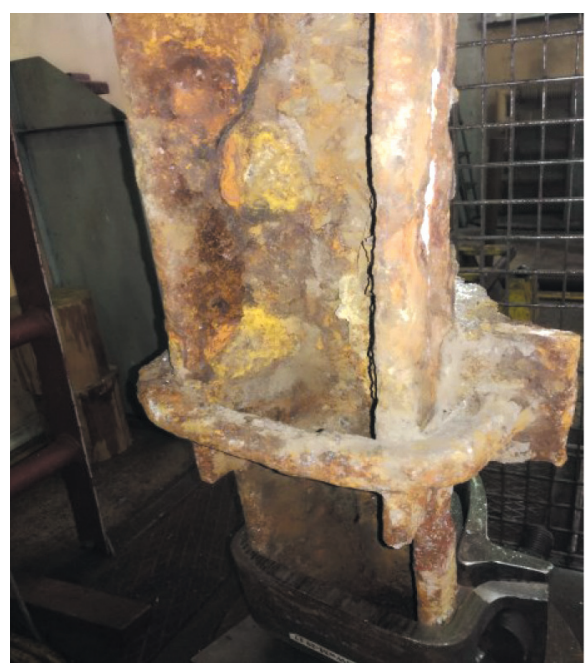

b)

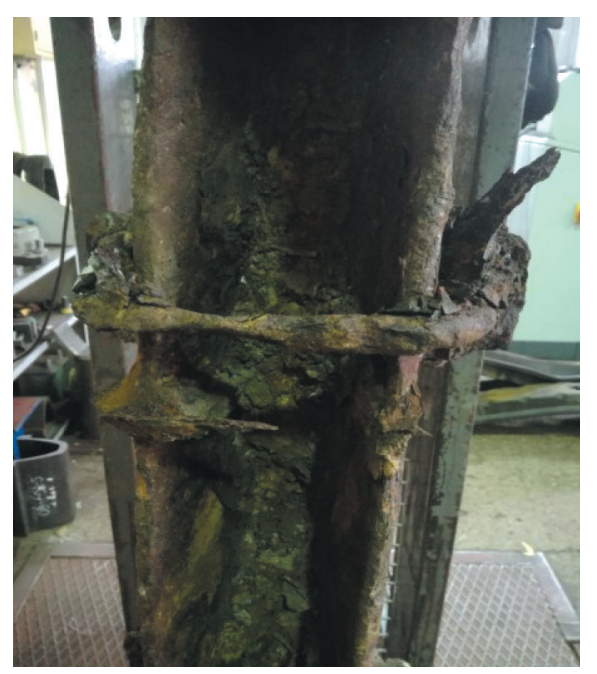

Fig. 7. Bow bolts in joints during testing: a) no. 1; b) no. 2

a)

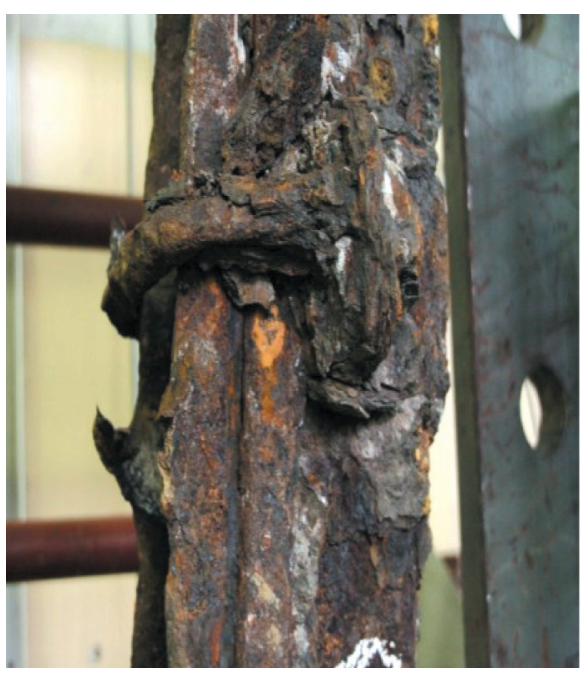

b)

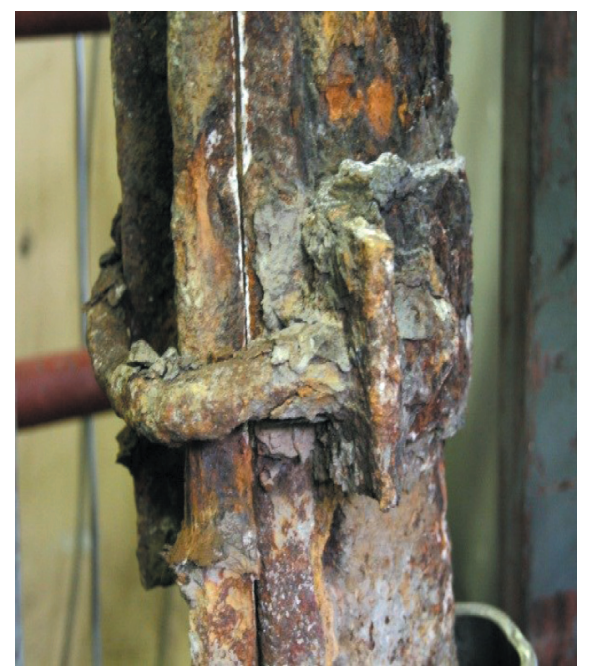

Fig. 8. Friction joint 2 shackles after testing (evident yield)

When yielding, bow bolts undergo slight beveling, which results in their increased tension as related to the nominal (generated by nominal tightening torque). Due to the fact that the bow bolts have a considerably reduced cross-section resulting from corrosion (Fig. 7), the bolts undergo significant deformation, which is the cause behind the decrease in section pressure force in the joint and, thus, the decrease in friction force. The low final section load capacity value in the joint (determined at a level of approx. $90 \mathrm{kN}$ ) and its character (lack of stepwise yielding typical of friction joints) are also influenced by the joint surface condition, which is covered with multiple corrosion products and stone dust. However, the extent of this in-fluence is very difficult to determine when considering a joint surface condition that is diversified to such a degree.

The conducted tests revealed the high load capacities of significantly corroded friction joints. This particularly concerns their state before the first yield. As can be observed, even major bow shackle corrosion damage (joint II) does not result in decreased joint load capacity (when it comes to the first yield) when compared to a new non-corroded joint. Thus, it can be assumed that (paradoxically enough) significant friction joint corrosion increases its load capacity. However, this concerns the state before the first yield and rupture of the corroded joint. Because of this, under conditions of major frame corrosion and the simultaneous "transformation" of friction joints 
into corroded arch joints, and in the case of no arch yielding occurring in the overlaps, questions of friction joint load capacity can be disregarded when qualifying corroded frames as suitable for further use, while the corroded frame load capacity assessment itself can be limited to arch strength.

\section{SUMMARY AND CONCLUSIONS}

The studies of very heavily corroded joints have shown that corrosion has a significant influence on the locking effect of sections in a joint. Depending on the condition of the shackles in a joint (which determine the section pressure force), corrosion may result in a complete blocking of the joint or a situation where its load capacity is much greater than the nominal load capacity. Paradoxically, this leads to an increase in the frame load capacity, as it then changes its characteristics from yielding to rigid. However, this occurs at the cost of its yielding capacity and results in hazardous situations where the support becomes rigid (which is unfavorable, particularly when faced with the possibility of rock mass tremors or deformational load occurrence). The low friction joint load capacity after the first yield (after the breakage of the adhesive joint) may be a cause for concern as well. It must also be taken into consideration that the maximum load capacity of the (rigid) frame decreases together with the progressing corrosion.

Due to the fact that the presented studies are of a pilot character, while the obtained results reveal a very significant influence of corrosion on the support operational safety, the studies of corroded joints will be continued using a larger number of samples and various types of shackles.

\section{References}

[1] Prusek S., Rotkegel M., Małecki Ł.: Wybrane sposoby wzmacniania skorodowanej stalowej obudowy odrzwiowej, "Przegląd Górniczy" 2015, 5: 71-77.

[2] Baszkiewicz J., Kamiński M.: Podstawy korozji materiałów, Oficyna Wydawnicza Politechniki Warszawskiej, Warszawa 1997.

[3] Graffstein-Malkiewicz E., Leśniewski K.: Korozja w górnictwie weglowym, Wydawnictwo "Śląsk", Katowice 1971.

[4] Prusek S., Rotkegel M.: Zjawisko korozji w obudowie chodnikowej, "Prace Naukowe GIG. Seria Konferencje" 2004, 48: 55-62.

[5] Rotkegel M.: Skutki korozji obudowy wyrobisk korytarzowych, sposoby im zapobiegania i minimalizacji strat, Konferencja WUG i GIG-SITG "Problemy bezpieczeństwa i ochrony zdrowia w polskim górnictwie”, Mysłowice 2006: 147-157.
[6] Wranglen G.: Podstawy korozji i ochrony metali, Wydawnictwa Naukowo-Techniczne, Warszawa 1985.

[7] Prusek S., Rotkegel M., Stokłosa J., Malesza A.: Ocena stopnia skorodowania odrzwi obudowy chodnikowej na przykładzie ZG "Bytom III", "Miesięcznik WUG" 2004, 9: 13-20.

[8] Prusek S., Rotkegel M.: Korozja obudowy wyrobisk korytarzowych, "Wiadomości Górnicze" 2005, 7-8: 336-341.

[9] Rak Z., Siodłak Ł., Stasica J.: Możliwości wzmocnienia obudowy podporowej wyrobisk korytarzowych $z$ wykorzystaniem torkretowania, "Bezpieczeństwo Pracy i Ochrona Środowiska w Górnictwie", 5, 2007.

[10] Rotkegel M., Kowalski E.: Wptyw stopnia skorodowania elementów odrzwi na nośność obudowy, "Prace Naukowe GIG. Seria Konferencje" 2003, 46: 95-110.

[11] Rotkegel M.: Pomiary ubytku korozyjnego obudowy wyrobisk korytarzowych, "Prace Naukowe GIG" 2006, 4: 23-32.

[12] Pytlik A.: Wplyw zginania na pracę ciernych złaczy łukowych odrzwi ŁP przy obciażeniach statycznych i dynamicznych, Główny Instytut Górnictwa, Katowice 2001 [praca doktorska].

[13] Pytlik A.: Charakterystyka pracy tukowych złaczy badanych z odporem biernym przy obciązeniu statycznym i dynamicznym, Prace Naukowe GIG. Seria Konferencje nr 42. Problemy obudowy i utrzymania wyrobisk korytarzowych, Katowice 2002: 109-123.

[14] Pytlik A.: Obudowa górnicza i jej akcesoria - wymogi bezpiecznego stosowania, in: Bezpieczeństwo pracy w kopalniach wegla kamiennego, red. W. Konopko, Górnictwo i środowisko, t. 1: Główny Instytut Górnictwa, Katowice 2013: 111-133.

[15] Rotkegel M.: Wplyw cech konstrukcyjnych złaczy na nośność stalowej obudowy odrzwiowej podatnej, "Wiadomości Górnicze" 2011, 9: 480-484.

[16] Chudek M. et al.: Zasady doboru i projektowania obudowy wyrobisk korytarzowych i ich połączeń w zaktadach górniczych wydobywających wegiel kamienny, Katedra Geomechaniki, Budownictwa Podziemnego i Ochrony Powierzchni, Politechnika Śląska, Gliwice-Kraków-Katowice 1999.

[17] Drzęźla B. et al.: Obudowa Górnicza. Zasady projektowania $i$ doboru obudowy wyrobisk korytarzowych $w$ zakładach górniczych wydobywajacych wegiel kamienny, wyd. 2 poprawione, Wydawnictwo Politechniki Śląskiej, Gliwice 2000.

[18] Rułka K. et al.: Uproszczone zasady doboru obudowy odrzwiowej wyrobisk korytarzowych $w$ zaktadach wydobywajacych węgiel kamienny, Główny Instytut Górnictwa, Seria Instrukcje, Nr 15, Katowice 2001.

[19] Materiały własne KWK Piast-Ziemowit.

[20] Norma PN-G-15026:2017-04: Obudowa wyrobisk górniczych strzemiona oraz złącza odrzwi z kształtowników korytkowych. Badania wytrzymałościowe.

RAJMUND HORST, M.Sc., Eng. MAREK MODRZIK, M.Sc., Eng. PAWEŁ FICEK, M.Sc., Eng. PGG KWK Piast-Ziemowit ul. Granitowa 16, 43-155 Bieruń, Poland \{r.horst,m.modrzik, p.ficek\}@pgg.pl

MAREK ROTKEGEL, Ph. D., Eng. ANDRZEJ PYTLIK, Ph. D., Eng. Central Mining Institute plac Gwarków 1, 40-166 Katowice, Poland \{mrotkegel,apytlik\}@gig.eu 


\title{
Badania nośności skorodowanych złączy ciernych obudowy odrzwiowej na przykładzie Kopalni Węgla Kamiennego Piast-Ziemowit
}

\begin{abstract}
$W$ artykule przedstawiono wyniki badań nośności skorodowanych złączy ciernych pozyskanych z przebudowy wyrobiska. Gtównym celem badań było określenie charakterystyk pracy silnie skorodowanych złączy ciernych oraz określenie ich nośności. Dodatkowym celem badan było wskazanie parametru skorodowanych odrzwi, kluczowego przy ocenie stanu technicznego obudowy - nośność złączy ciernych czy wytrzymałość łuków. $W$ artykule scharakteryzowano również w skrócie warunki kopalniane, w których pracowata obudowa $€ P$.

$W$ związu $z$ tym, że omówione $w$ artykule badania maja charakter pilotażowy, a uzyskane wyniki wskazuja na znaczny wptyw korozji na bezpieczeństwo pracy obudowy, badania skorodowanych złaczy będa kontynuowane na większej liczbie próbek oraz przy różnych typach strzemion.
\end{abstract}

Słowa kluczowe: korozja, obudowa wyrobisk, złącza cierne, badanie nośności

\section{WPROWADZENIE}

Stalowa obudowa odrzwiowa jest podstawową obudową wyrobisk korytarzowych stosowaną w polskich kopalniach węgla kamiennego. Wynika to z wielu zalet takiej obudowy, między innymi z łatwego dostosowania jej do warunków geologiczno-górniczych, szybkiego jej wykonywania, stosunkowo niskiej ceny, a także z szerokiego wachlarza dostępnych wariantów wymiarowych obudowy. Pomimo tego stalowa obudowa odrzwiowa ma istotną wadę. Jej nośność jest zmienna w czasie wraz z postępującą korozją odrzwi. Zatem jej trwałość jest ograniczona i zależy między innymi od agresywności środowiska, w którym jest zastosowana. $\mathrm{Na}$ podstawie obserwacji dołowych można stwierdzić, że stalowe obudowy odrzwiowe zachowują swą funkcjonalność w czasie od kilku do kilkudziesięciu lat. Oczywiste jest to, że poszczególne elementy składowe obudowy odrzwiowej w różnym stopniu wrażliwe są na działanie agresywnego środowiska. Zdecydowanie większa jest trwałość odrzwi niż elementów cienkościennych, takich jak siatki okładzinowe czy rozpory międzyodrzwiowe. O ile w przypadku znacznego skorodowania większości akcesoriów możliwe jest ich uzupełnienie, wymiana lub zastosowanie zestawów naprawczych, o tyle w przypadku odrzwi konieczne jest ich wzmocnienie (podbudowanie) lub wymiana, związana z kosztowną przebudowa wyrobiska [1]. Dla uniknięcia sytuacji awaryjnych, kiedy nośność obudowy spada do poziomu obciążeń na nią działających i grozi utratą stateczności wyrobiska, a także obwałami i zawałami prowadzone są przez służby kopalniane okresowe kontrole stanu technicznego obudowy. Dotychczas prowadzono szereg badań nad korozją, także obudowy górniczej [2-6] i opracowanych zostało wiele metod pozwalających 
na oszacowanie nośności skorodowanych odrzwi na podstawie pomiarów rzeczywistej grubości ścianek kształtowników V [7-11]. Bardzo istotnym zagadnieniem jest także nośność złączy ciernych [12-15], która wpływa na rozstaw odrzwi, określany w procesie doboru obudowy [16-18], a w przytoczonych metodach oceny obudowy skorodowanej jest pomijana. Trudno jest bowiem w warunkach dołowych określić czy chociaż oszacować nośność złączy ciernych, w których na skutek zjawiska korozji szczelinowej nastąpiło zescalenie łuków obudowy. Dla oszacowania tej nośności przeprowadzono cykl badań stanowiskowych na złączach ciernych odrzwi, pozyskanych z przebudowanego wyrobiska. Dodatkowym celem badań było wskazanie, który parametr (nośność złączy ciernych czy wytrzymałość łuków) jest kluczowy w ocenie stanu technicznego skorodowanej obudowy.

\section{CHARAKTERYSTYKA \\ ŚRODOWISKA KOPALNIANEGO W MIEJSCU PRACY BADANYCH ZŁĄCZY CIERNYCH}

Środowisko kopalniane zmienia się wraz z charakterystycznymi czynnikami, takimi jak: warunki hydrologiczne, głębokość zalegania, wilgotność, temperatura pierwotna skał otaczających, temperatura maszyn i urządzeń pracujących w danym wyrobisku, przepływ powietrza itp. Na podstawie badań i obserwacji stwierdzono, że największy wpływ na prędkość procesów korozji w KWK Piast-Ziemowit Ruch Ziemowit ma agresywność wód kopalnianych.
O agresywności wód kopalnianych decydują cztery podstawowe składniki zawarte w wodach:

- stężenie jonów wodorowych $(\mathrm{pH})$,

- twardość ogólna,

- ilość chlorków,

- ilość siarczanów.

Próbki złączy ciernych przeznaczone do badań laboratoryjnych pobrano z przekopu wschodniego 930, poziom III $(650 \mathrm{~m}) \mathrm{w}$ trakcie prowadzonej tam przebudowy. W tabeli 1 zebrano podstawowe dane dotyczące obudowy.

Obudowa została zabudowana w 1998 r., zatem eksploatowana była przez 20 lat. Na łukach obudowy widoczne są odspojenia produktów korozji oraz silnie skorodowane strzemiona. Środowisko w miejscu pobierania próbek jest bardzo agresywne. W wyrobisku panuje wilgotność względna powietrza na poziomie $88 \%$. Dodatkowo analizowana woda charakteryzuje się bardzo wysoką mineralizacją. Zawiera ona $149500 \mathrm{mg} / \mathrm{dm}^{3}$ substancji rozpuszczonych oraz posiada wysoką twardość $-1019^{\circ} \mathrm{n}$. Średnie stężenie jonów chlorków $84373 \mathrm{mg} / \mathrm{dm}^{3}$ oraz siarczanów $3323 \mathrm{mg} / \mathrm{dm}^{3}$ przy znacznej warstwie wilgoci na powierzchni obudowy wpływa na przyspieszenie procesów korozyjnych. Kationy magnezu $3466 \mathrm{mg} / \mathrm{dm}^{3}$ oraz wapnia $4280 \mathrm{mg} / \mathrm{dm}^{3}$ wpływają natomiast na znaczną twardość wody.

Biorąc pod uwagę czas eksploatacji obudowy oraz bardzo wysoką jak na warunki kopalniane mineralizację wody skraplającej się na powierzchni obudowy powodującą przyspieszenie procesów korozji, obudowę wraz z złączami ciernymi w przekopie wschodnim 930 można ocenić jako silnie skorodowaną.

Tabela 1

Charakterystyka obudowy [19]

\begin{tabular}{|c|c|c|c|c|c|}
\hline $\begin{array}{c}\text { Wielkość } \\
\text { odrzwi }\end{array}$ & Ksztaltownik & $\begin{array}{c}\text { Gatunek } \\
\text { stali }\end{array}$ & $\begin{array}{c}\text { Liczba } \\
\text { strzemion } \\
\text { w zlączu }\end{array}$ & $\begin{array}{c}\text { Typ } \\
\text { strzemion }\end{array}$ & $\begin{array}{c}\text { Rok } \\
\text { zabudowy }\end{array}$ \\
\hline ŁP9 & V29 & $25 \mathrm{G} 2$ & 2 & K29 & $1998 \mathrm{r}$. \\
\hline
\end{tabular}

Tabela 2

Właściwości fizykochemiczne wody w miejscu eksploatacji badanej obudowy [19]

\begin{tabular}{|c|c|c|c|c|c|c|c|}
\hline \multirow{2}{*}{$\begin{array}{c}\text { Substancje } \\
\text { rozpuszczone } \\
{\left[\mathbf{m g} / \mathbf{d m}^{3}\right]}\end{array}$} & $\mathbf{p H}$ & \multirow{2}{*}{$\begin{array}{c}\text { Twardość } \\
\text { ogólna } \\
{\left[{ }^{\circ} \mathbf{n}\right]}\end{array}$} & \multicolumn{2}{|c|}{$\begin{array}{c}\text { Kationy } \\
{\left[\mathrm{mg} / \mathbf{d m}^{3}\right]}\end{array}$} & \multicolumn{3}{|c|}{$\begin{array}{c}\text { Aniony } \\
{\left[\mathrm{mg} / \mathbf{d m}^{3}\right]}\end{array}$} \\
\cline { 5 - 8 } & & & $\mathrm{Ca}^{+2}$ & $\mathrm{Mg}^{+2}$ & $\mathrm{Cl}^{-}$ & $\mathrm{SO}_{4}{ }^{-2}$ & $\mathrm{HCO}_{3}{ }^{-}$ \\
\hline 149500 & 6,5 & 1386 & 4280 & 3466 & 84373 & 3323 & 122 \\
\hline
\end{tabular}




\section{PRZEBIEG I WYNIKI BADAŃ}

Badania stanowiskowe przeprowadzono na dwóch złączach ciernych obudowy ŁP z kształtownika V29 pozyskanych $\mathrm{w}$ trakcie przebudowy przekopu wschodniego 930 na poziomie III w KWK Piast-Ziemowit Ruch Ziemowit.

Badania złączy łukowych elementów bez odporu biernego (siły biernej oddziałującej na złącze) przeprowadzono według schematu obciążeniowego przedstawionego na rysunku 1 , na podstawie normy PN-G-15026:2017-04 [20].

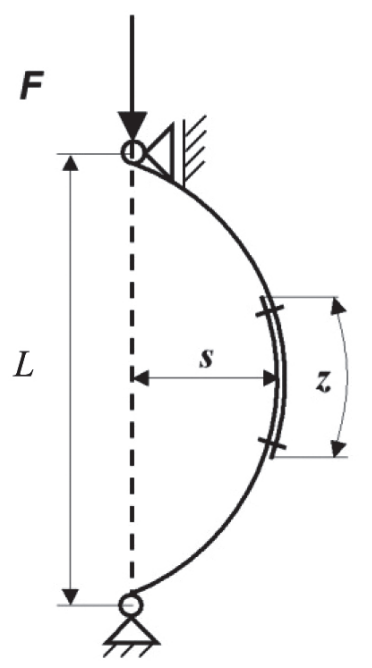

Rys. 1. Schemat obciążenia złączy tukowych elementów siła $F$ działajaca w osi przegubu podpory stałej, gdzie: L - długość cięciwy złącza, s-długość strzatki złącza, z-długość zakładki

Wartość ujemnego momentu zginającego $M_{g}$ (powodującego zmniejszenie promienia krzywizny łuków złącza) w przekroju złącza, w miejscu jego strzałki $s$, została obliczona ze wzoru:

$$
M_{g}=-F \cdot s[\mathrm{kN} \cdot \mathrm{m}]
$$

gdzie:

$F$ - siła obciążająca złącze w momencie jego zsuwu $[\mathrm{kN}]$,

$s$ - długość strzałki [m] złącza, obliczona jako odległość między osią obojętną dwóch kształtowników V29 w złączu a osią działania siły $F$.

Stanowisko badawcze wyposażone było w siłownik hydrauliczny z zamontowanym w tłoczysku tensometrycznym czujnikiem siły (pracującym w układzie pełnego mostka) o zakresie pomiarowym do $1000 \mathrm{kN}$ (klasa 0,5) oraz w potencjometryczny przetwornik przemieszczenia, o zakresie pomiarowym do $1500 \mathrm{~mm}$ (klasa 0,35 ), do pomiaru zmiany długości $\Delta L$ cięciwy złącza podczas jego obciążania.

Podczas badań mierzono siłę $F$ obciążającą złącze oraz długość cięciwy c złącza z częstotliwością próbkowania $f_{p}=10 \mathrm{~Hz}$, która (jak wykazały wieloletnie doświadczenia z badań złączy ciernych w ramach laboratorium akredytowanego) jest wystarczająca do określenia charakterystyki pracy złączy ciernych odrzwi obudowy ŁP. Czujniki połączone były do wzmacniacza pomiarowego typu DMCplus wykonanego w klasie dokładności 0,03. Dane pomiarowe rejestrowane były na komputerze za pomoca programu CATMAN.

Przed badaniem złącza miały zakładkę ok. $560 \mathrm{~mm}$, natomiast strzałki s złączy miały wartość ok. $108 \mathrm{~mm}$ (pomiar od osi działania siły $F$ do osi obojętnej złącza) $[12,13]$.

Końce złączy stykające się z równoległymi do siebie płytami obciążającymi maszyny wytrzymałościowej zostały tak przycięte, aby przylegały do płyt maszyny. W związku z tym, że stwierdzono perforację kształtowników w złączu (rys. 2), jego końce dodatkowo wzmocniono odcinkiem kształtownika V29 oraz pojedynczym strzemieniem. Miało to na celu niedopuszczenie do deformacji kształtowników V29 w złączu, co zablokowałoby jego zsuwanie, a tym samym zniekształciło przebieg pracy złącza. Widok złączy przygotowanych do badań przedstawiono na rysunkach 3 i 4 .

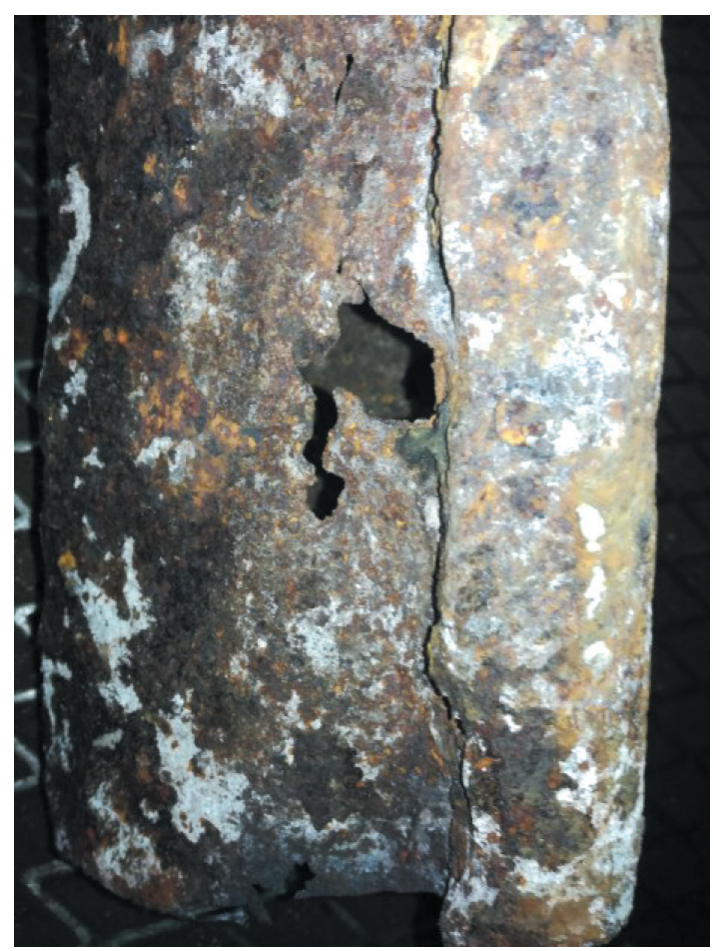

Rys. 2. Perforacja kształtownika $w$ rejonie jego kotnierza 

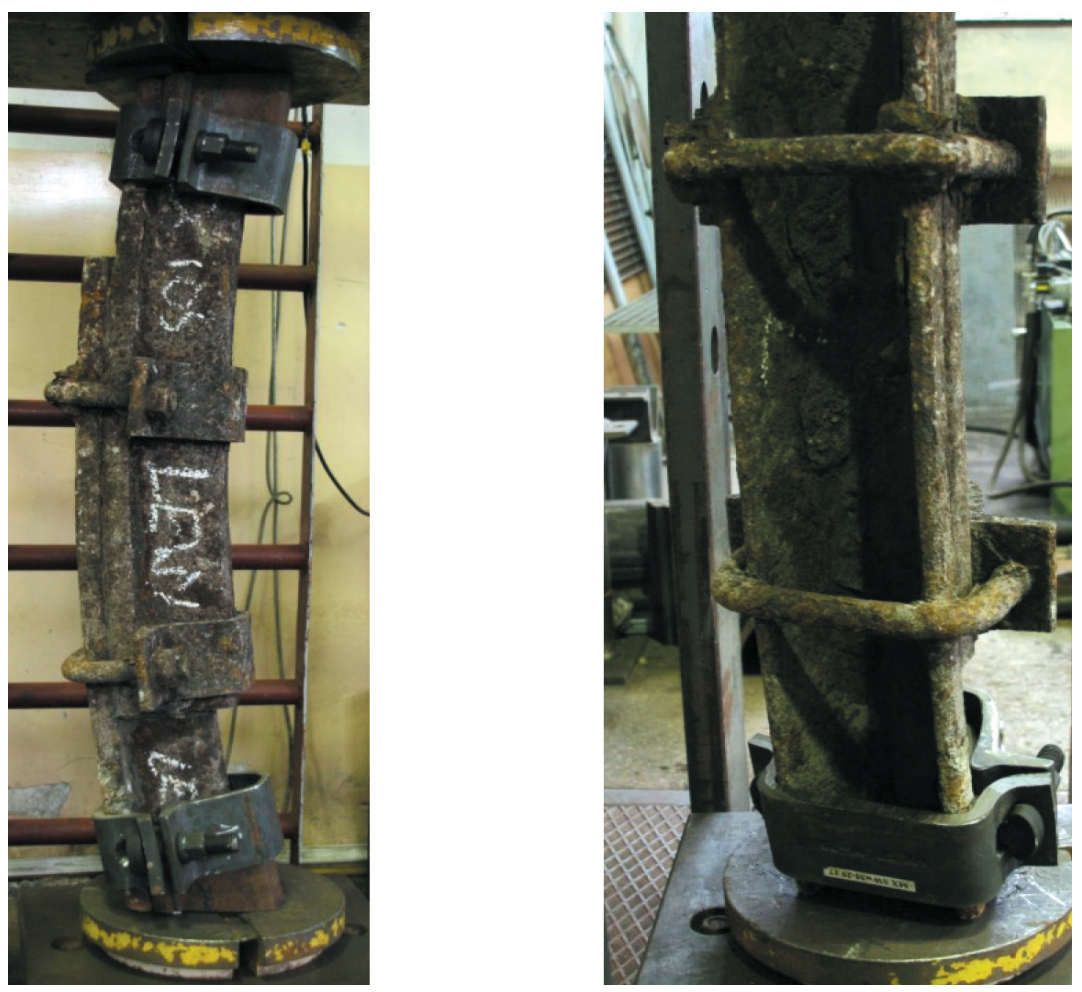

Rys. 3. Złacze cierne 1 przygotowane do badań $i$ stan techniczny strzemion
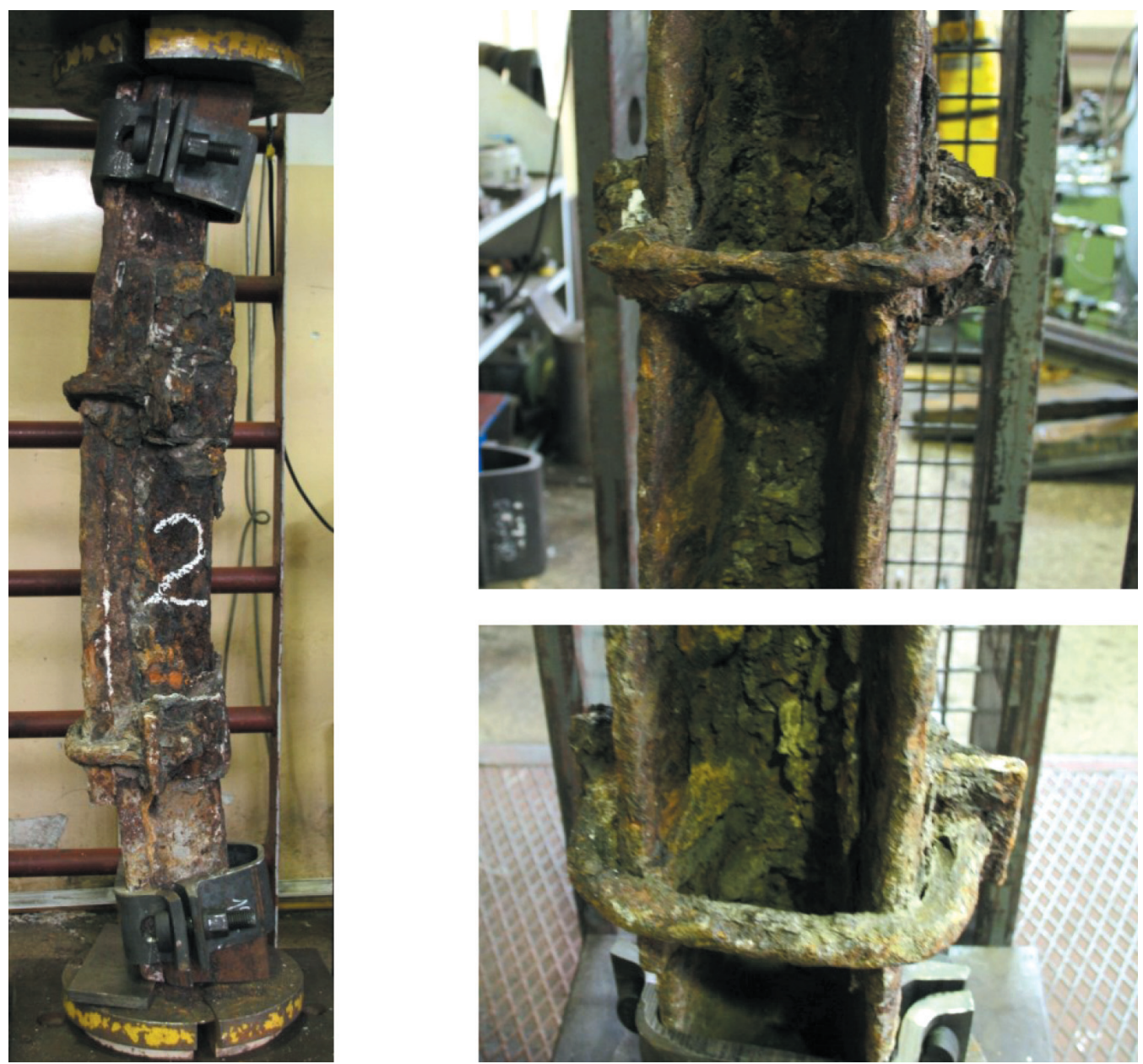

Rys. 4. Złacze cierne 2 przygotowane do badań i stan techniczny strzemion 
Wyniki badań w postaci przebiegów $F=f(\Delta L)$ przedstawiono na rysunkach 5 i 6 .

Pomiary geometryczne strzemion kabłąkowych typu K29 w złączu nr 1 wykazały, że śruby kabłąkowe M27 posiadają nieznaczne ubytki korozyjne skutkujące zmniejszeniem się średnicy kabłąków do 25-26 mm zarówno w strzemieniu dolnym jak i górnym. Zmierzona przed i po badaniu zakładka złącza $z=560 \mathrm{~mm}$ nie uległa zmianie.

Złącze podczas próby $\mathrm{nr} 1$ obciążone siłą $F=700 \mathrm{kN}$, przy momencie zginającym $M_{\mathrm{g}}=75,6 \mathrm{kNm}$, nie zsunęło się, a po próbie nie stwierdzono również je- go deformacji plastycznej. Łukowe złącza wykonane z kształtowników V29 połączonych dwoma strzemionami typu K29 zsuwają się zwykle przy sile obciążającej ok. 220 kN. Zablokowanie się złącza jest najprawdopodobniej wynikiem korozji szczelinowej pomiędzy łukami, która doprowadziła do sczepienia się kształtowników i strzemion w złączu.

Pomiary geometryczne strzemion kabłąkowych typu K29 w złączu nr 2 wykazały, że śruby kabłąkowe M27 posiadają znaczne ubytki korozyjne skutkujące zmniejszeniem się średnicy kabłąków do 7-20 mm w strzemieniu górnym oraz do 18-23 mm w strzemieniu dolnym.

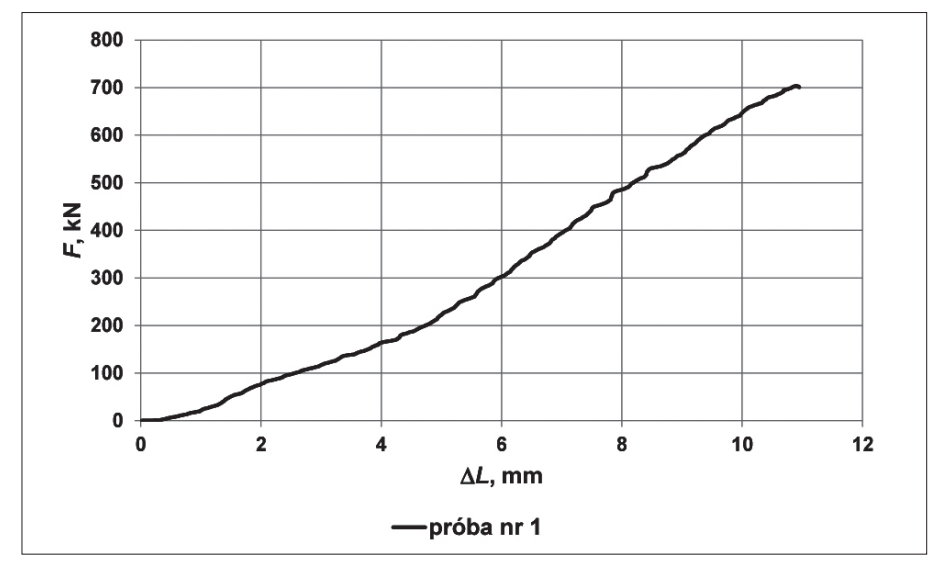

Rys. 5. Charakterystyka złącza ciernego 1

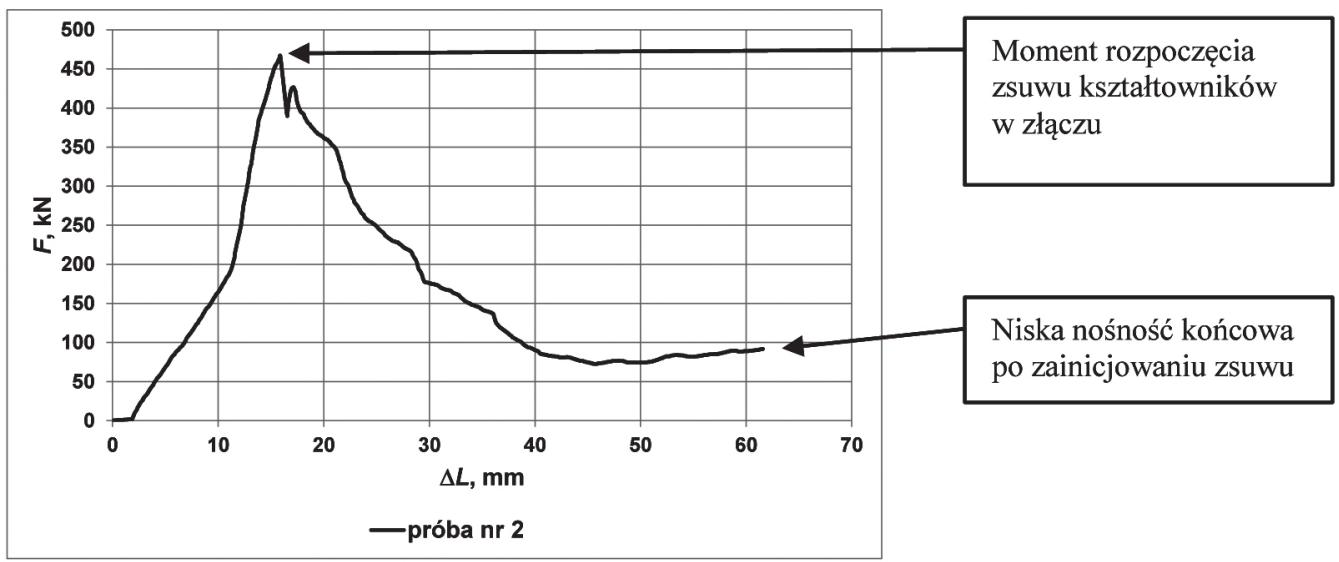

Rys. 6. Charakterystyka złącza ciernego 2

Odmienny charakter pracy zaobserwowano podczas próby nr 2. Złącze obciążone siłą $F=467 \mathrm{kN}$, przy momencie zginającym $M_{\mathrm{g}}=50,4 \mathrm{kNm}$, zsunęło się (rys. 8). Zsuw miał charakter zsuwu ciągłego, a końcowa wartość nośności złącza ustabilizowała się na poziomie ok. $90 \mathrm{kN}$. Po próbie nie stwierdzono również deformacji plastycznej kształtowników w złączu. Najbardziej prawdopodobną przyczyną zsuwu złącza oraz systematycznym jej obniżaniem się był zły stan techniczny śrub kabłąkowych górnego i dolnego strzemienia w porównaniu z kabłąkami strzemion użytych w próbie nr 1 (rys. 7). Śruby kabłąkowe podczas zsuwu ulegają lekkiemu ukosowaniu, co wywołuje w nich zwiększoną siłę naciągu w stosunku do nominalnej (wywołanej nominalnym momentem dokręcenia). Ponieważ śruby kabłąkowe mają znacznie zmniejszony przekrój spowodowany korozją (rys. 7), ulegają one znacznemu odkształceniu, co jest przyczyną zmniejszenia docisku kształtowników w złączu, a tym samym zmniejszenia się siły tarcia. 
a)

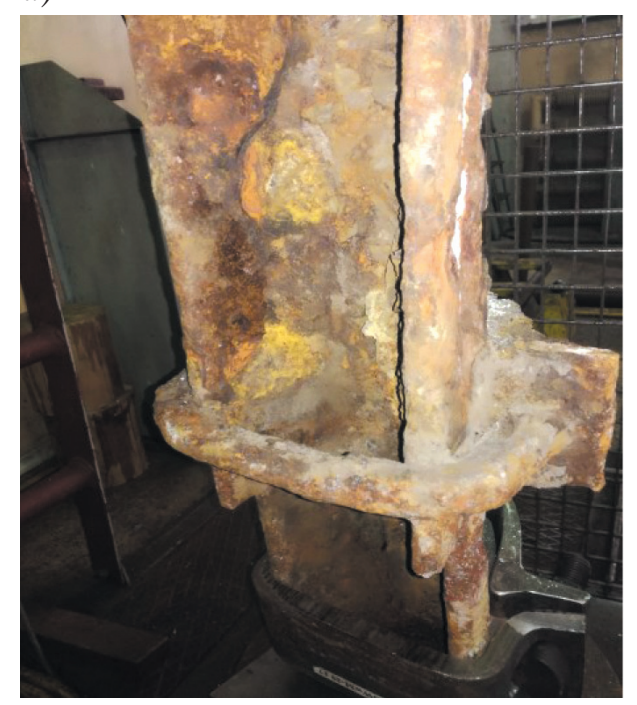

b)

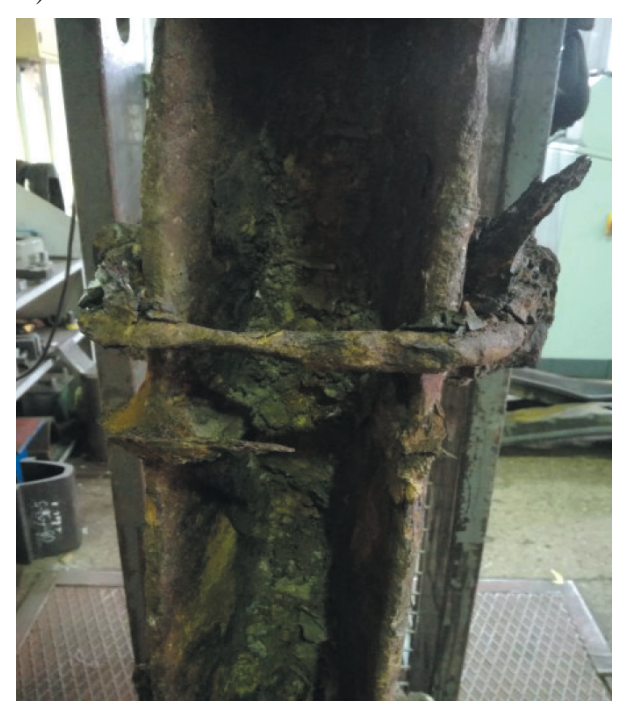

Rys. 7. Śruby kabtąowe w złaczach podczas prób: a) nr 1; b) nr 2

a)

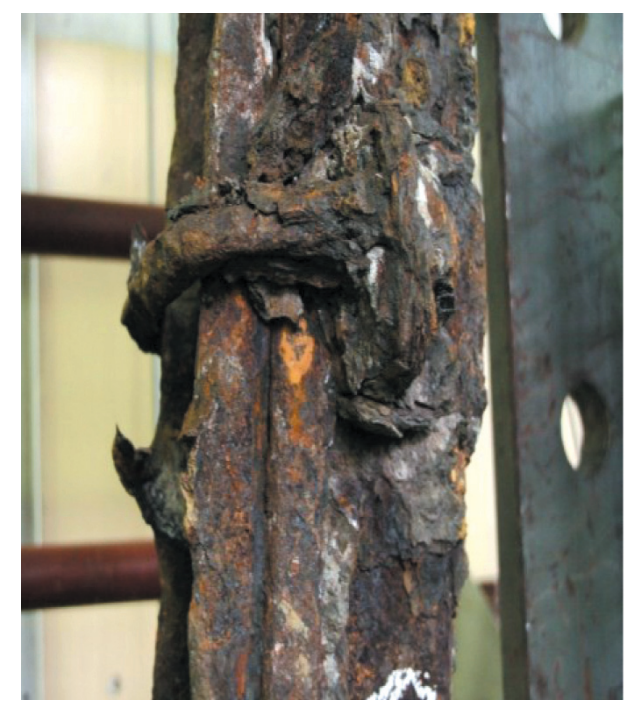

b)

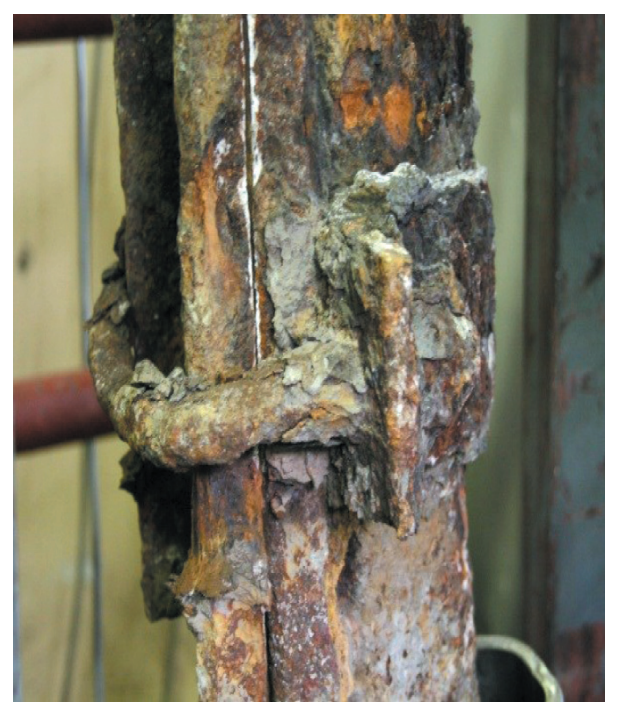

Rys. 8. Strzemiona złacza ciernego 2 po badaniach (widoczny zsuw)

Na niską wartość nośności końcowej złącza (ustaloną na poziomie ok. $90 \mathrm{kN}$ ) i jej charakter (brak typowych dla ciernego złącza skokowych zsuwów) ma również wpływ stan powierzchni złącza, które pokryte jest licznymi produktami korozji oraz pyłem kamiennym, wielkość tego wpływu jest jednak bardzo trudna do określenia przy tak różnorodnym stanie powierzchni złącza.

Przeprowadzone próby wykazały dużą nośność złączy ciernych, skorodowanych w znacznym stopniu. Szczególnie dotyczy to stanu przed wystąieniem pierwszego zsuwu. Jak widać, nawet znaczny ubytek korozyjny strzemion kabłąkowych (złącze II) nie powoduje obniżenia nośności złącza (w zakresie pierwszego zsuwu) w stosunku do złącza nowego nieskorodowanego. Można zatem przyjmować, że (paradoksalnie) znaczna korozja złączy ciernych podnosi ich nośność. Dotyczy to jednak stanu przed pierwszym zsuwem i zerwaniem złącza korozyjnego. W związku z tym w warunkach znacznego zużycia korozyjnego odrzwi, przy jednoczesnym „przejściu” złączy ciernych w złącza korozyjne łuków oraz w przypadku niewystąpienia zsuwów łuków w zakładkach, w kwalifikowaniu skorodowanych odrzwi jako nadających się do dalszej pracy kwestie nośności złączy ciernych mogą zostać pominięte, a sama ocena nośności skorodowanych odrzwi może być ograniczona do wytrzymałości łuków. 


\section{PODSUMOWANIE I WNIOSKI}

Badania bardzo silnie skorodowanych złączy wykazały, że korozja ma znaczący wpływ na powstanie efektu sczepiania się kształtowników w złączu. W zależności od stanu strzemion w złączu, które decydują o sile docisku kształtowników, korozja może doprowadzić do całkowitego zablokowania się złącza lub sytuacji, gdy jego nośność jest znacznie większa od nośności nominalnej. Paradoksalnie prowadzi to do wzrostu nośności odrzwi, gdyż zmienia się ich charakterystyka z podatnej na sztywną. Odbywa się to jednak kosztem ich podatności i prowadzi do niebezpiecznej sytuacji usztywnienia się obudowy, co w konsekwencji jest niekorzystne, zwłaszcza w przypadkach możliwości występowania wstrząsów górotworu, czy też obciążeń o charakterze deformacyjnym. Niepokój może także budzić niewielka nośność złącza ciernego po zaistnieniu pierwszego zsuwu, po zerwaniu połączenia adhezyjnego. Należy także mieć na uwadze fakt, że wraz z postępującą korozją maksymalna nośność odrzwi (usztywnionych) spada.

W związku z tym, że przedstawione badania mają charakter pilotażowy, a uzyskane wyniki wskazują na bardzo znaczący wpływ korozji na bezpieczeństwo pracy obudowy, badania skorodowanych złączy będą kontynuowane na większej liczbie próbek oraz przy różnych konfiguracjach strzemion.

\section{Literatura}

[1] Prusek S., Rotkegel M., Małecki Ł.: Wybrane sposoby wzmacniania skorodowanej stalowej obudowy odrzwiowej, „Przegląd Górniczy" 2015, 5: 71-77.

[2] Baszkiewicz J., Kamiński M.: Podstawy korozji materiałów, Oficyna Wydawnicza Politechniki Warszawskiej, Warszawa 1997.

[3] Graffstein-Malkiewicz E., Leśniewski K.: Korozja w górnictwie węlowym, Wydawnictwo „Śląsk”, Katowice 1971.

[4] Prusek S., Rotkegel M.: Zjawisko korozji w obudowie chodnikowej, „Prace Naukowe GIG. Seria Konferencje” 2004, 48: 55-62.

[5] Rotkegel M.: Skutki korozji obudowy wyrobisk korytarzowych, sposoby im zapobiegania i minimalizacji strat, Konferencja WUG i GIG-SITG „Problemy bezpieczeństwa i ochrony zdrowia w polskim górnictwie", Mysłowice 2006: 147-157.

[6] Wranglen G.: Podstawy korozji $i$ ochrony metali, Wydawnictwa Naukowo-Techniczne, Warszawa 1985.

[7] Prusek S., Rotkegel M., Stokłosa J., Malesza A.: Ocena stopnia skorodowania odrzwi obudowy chodnikowej na przykładzie ZG „Bytom III”, „Miesięcznik WUG” 2004, 9: 13-20.
[8] Prusek S., Rotkegel M.: Korozja obudowy wyrobisk korytarzowych, „Wiadomości Górnicze” 2005, 7-8: 336-341.

[9] Rak Z., Siodłak Ł., Stasica J.: Możliwości wzmocnienia obudowy podporowej wyrobisk korytarzowych $z$ wykorzystaniem torkretowania, „Bezpieczeństwo Pracy i Ochrona Środowiska w Górnictwie”, 5, 2007.

[10] Rotkegel M., Kowalski E.: Wpływ stopnia skorodowania elementów odrzwi na nośność obudowy, „Prace Naukowe GIG. Seria Konferencje” 2003, 46: 95-110.

[11] Rotkegel M.: Pomiary ubytku korozyjnego obudowy wyrobisk korytarzowych, „Prace Naukowe GIG” 2006, 4: 23-32.

[12] Pytlik A.: Wpływ zginania na prace ciernych złączy łukowych odrzwi ŁP przy obciązeniach statycznych $i$ dynamicznych, Główny Instytut Górnictwa, Katowice 2001 [praca doktorska].

[13] Pytlik A.: Charakterystyka pracy łukowych złączy badanych z odporem biernym przy obciażeniu statycznym i dynamicznym, „Prace Naukowe GIG. Seria Konferencje nr 42. Problemy obudowy i utrzymania wyrobisk korytarzowych", Katowice 2002: 109-123.

[14] Pytlik A.: Obudowa górnicza i jej akcesoria - wymogi bezpiecznego stosowania, w: Bezpieczeństwo pracy w kopalniach węgla kamiennego, red. W. Konopko, t. 1: Górnictwo i środowisko, Główny Instytut Górnictwa, Katowice 2013: 111-133.

[15] Rotkegel M.: Wpływ cech konstrukcyjnych złaczy na nośność stalowej obudowy odrzwiowej podatnej, „Wiadomości Górnicze" 2011, 9: 480-484.

[16] Chudek M. et al.: Zasady doboru i projektowania obudowy wyrobisk korytarzowych i ich połaczeń $w$ zakładach górniczych wydobywajacych wegiel kamienny, Katedra Geomechaniki, Budownictwa Podziemnego i Ochrony Powierzchni, Politechnika Śląska, Gliwice-Kraków-Katowice 1999.

[17] Drzęźla B. et al.: Obudowa górnicza. Zasady projektowania i doboru obudowy wyrobisk korytarzowych $w$ zakładach górniczych wydobywajacych wegiel kamienny, wyd. 2 poprawione, Wydawnictwo Politechniki Śląskiej, Gliwice 2000.

[18] Rułka K. et al.: Uproszczone zasady doboru obudowy odrzwiowej wyrobisk korytarzowych $w$ zakładach wydobywających węgiel kamienny, Główny Instytut Górnictwa, Seria Instrukcje, nr 15, Katowice 2001.

[19] Materiały własne KWK Piast-Ziemowit.

[20] Norma PN-G-15026:2017-04: Obudowa wyrobisk górniczych strzemiona oraz złącza odrzwi z kształtowników korytkowych. Badania wytrzymatościowe.

mgr inż. RAJMUND HORST mgr inż. MAREK MODRZIK mgr inz. PAWEŁ FICEK

PGG KWK Piast-Ziemowit ul. Granitowa 16, 43-155 Bieruń \{r.horst,m.modrzik, p.ficek\}@pgg.pl

dr inz. MAREK ROTKEGEL dr inż. ANDRZEJ PYTLIK Główny Instytut Górnictwa plac Gwarków 1, 40-166 Katowice \{mrotkegel, apytlik\}@gig.eu 